\title{
Dielectric and pyroelectric properties of the composites of ferroelectric ceramic and poly(vinyl chloride)
}

\author{
M.Olszowy \\ Institute of Physics, University of Zielona Góra, \\ 4a Szafrana Str., 65-516 Zielona Góra, Poland \\ Received October 24, 2002, in final form April 14, 2003
}

\begin{abstract}
The dielectric and pyroelectric properties of lead zirconate titanate/poly(vinyl chloride) [PZT/PVC] and barium titanate/poly(vinyl chloride) $\left[\mathrm{BaTiO}_{3} /\right.$ PVC] composites were studied. Flexible composites were fabricated in the thin films form $(200-400 \mu \mathrm{m})$ by hot-pressed method. Powders of PZT or $\mathrm{BaTiO}_{3}$ in the shape of $\leqslant 75 \mu \mathrm{m}$ ceramics particles were dispersed in a PVC matrix, providing composites with $0-3$ connectivity. Distribution of the ceramic particles in the polymer phase was examined by scanning electron microscopy. The analysis of the thermally stimulated currents (TSC) have also been done. The changes of dielectric and pyroelectric data on composites with different contents of ceramics up to $40 \%$ volume were investigated. The dielectric constants were measured in the frequency range from $600 \mathrm{~Hz}$ to $6 \mathrm{MHz}$ at room temperature. The pyroelectric coefficient for $\mathrm{BaTiO}_{3} / \mathrm{PVC}$ composite at $343 \mathrm{~K}$ is about $35 \mu \mathrm{C} / \mathrm{m}^{2} \mathrm{~K}$ which is higher than that of $\beta$-PVDF $\left(10 \mu \mathrm{C} / \mathrm{m}^{2} \mathrm{~K}\right)$.
\end{abstract}

Key words: pyroelectric composite, dielectric properties, pyroelectric properties, $\mathrm{PZT} / \mathrm{PVC}, \mathrm{BaTiO}_{3} / \mathrm{PVC}$

PACS: $77.84 . L, 77.70,77.84 . D$

\section{Introduction}

Electroactive composites consisting of a ferroelectric ceramic in a polymer matrix have gained much interest as compliant electromechanical or pyroelectric sensor. The composite materials are mixtures that contain two phases: filler of ceramic and matrix of polymer, where the fillers are included in the matrix in order to modify its physical properties in a high range. As the fillers there are applied $\mathrm{PZT}, \mathrm{BaTiO}_{3}$, $\mathrm{PbTiO}_{3}$ ceramics, and the mentioned ceramics with different dopings as well [1]. Ferroelectric ceramic/polymer composites with 0-3 connectivity pattern owe their popularity to the easy fabrication procedure which allows for mass production at a relatively low cost [2]. 
The obtained composites $0-3$ connectivity would exhibit the pyroelectric properties of ceramics and flexibility, strength and lightness of the polymer. The characteristics of the grains of the ceramic powder in these composites also cause their practical relevance. This is because the properties of ceramics depend not only on the composition and their crystal structure but also on the microstructure morphology including grain size, grain boundaries, pores, crystallinity, micro-cracks, etc. [2].

The electroactivity of ceramic/polymer composites has been reviewed by DasGupta [2,3] who also significantly contributed to the knowledge of dielectric and pyroelectric properties of the composites. Recently, the authors [4,5] discussed the pyroelectric properties of the composites.

In this paper, we will describe dielectric and pyroelectric properties of PZT/PVC and $\mathrm{BaTiO}_{3}$ /PVC composites of 0-3 connectivity prepared of local components fabricated in our laboratories. The dielectric characteristics we studied are important in determining the figures of merit $(p / \epsilon)$ and the operation temperature range of pyroelectric composites. Distribution of the ceramic grain and size grain in the polymer phase was inspected by the scanning electron microscopy.

\section{Sample preparation and experimental technique}

The 0-3 composites reported in the paper were prepared by hot-pressing (3.2 MPa pressure at $\sim 300 \mathrm{~K}$ has been applied) of the powder mixture and cooled to room temperature under pressure at a rate of $8 \mathrm{~K} / \mathrm{min}$. The fine powders of PZT or $\mathrm{BaTiO}_{3}$ in the shape of $\leqslant 75 \mu \mathrm{m}$ ceramics grains were dispersed in suspension PVC. Distribution of the ceramic grains in the PVC matrix and of the grains size was examined by the scanning electron microscopy (SEM). As a result of vacuum evaporation on both sides of flexible polymer and composite sample films 200-400 $\mu \mathrm{m}$ thick circular gold electrodes of $10 \mathrm{~mm}$ diameter have been gained. The dielectric and pyroelectric properties of composites with different content of ceramics were investigated. Dielectric constants and $\tan \delta$ were studied by using computer aided hp-4192 ALF impedance analyzer in the frequency range from $600 \mathrm{~Hz}$ to $6 \mathrm{MHz}$ at room temperature. The sample has been polarized at $T_{\mathrm{p}}=373 \mathrm{~K}$ for $t_{\mathrm{p}}=0.5 \mathrm{~h}$ in an DC electrical field $E_{\mathrm{p}}=1-4 \mathrm{MV} / \mathrm{m}$. Pyroelectric current and thermally stimulated currents (TSC) have been measured at the constant heating rate of $\beta=2.6 \mathrm{~K} / \mathrm{min}$ for short-circuited samples. Pyroelectric measurements were performed on composites using a quasi-static method. The pyroelectric coefficient is calculated from formula $p=I / A \beta$, where $I$ is the pyrocurrent and $A$ is the electrode surface.

\section{Results and discussion}

The PZT/PVC and $\mathrm{BaTiO}_{3} / \mathrm{PVC}$ composites with different contents of ceramics $0-40 \%$ were prepared. An admixture of the $\mathrm{PZT}$ or $\mathrm{BaTiO}_{3}$ added to the $\mathrm{PVC}$ brings a change of the dielectric and electro-active properties of the polymer which determine the pyroelectricity of the material. Figure 1 shows the variation of dielectric constant $\epsilon$ with ceramics volume ratio at the room temperature. The measured 


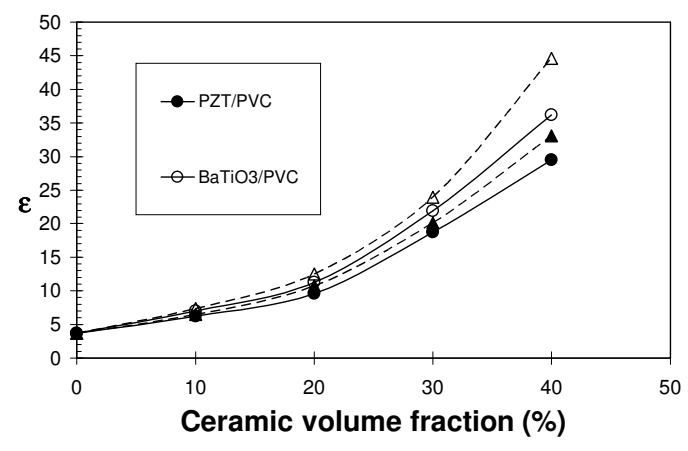

Figure 1. Dielectric constant as a function of ceramics volume fraction at $1 \mathrm{kHz}$. The dashed curves with $\boldsymbol{\Delta}$ and $\triangle$ are calculated with Lichtenecker mixing rule and apply to fillers PZT and $\mathrm{BaTiO}_{3}$, respectively.

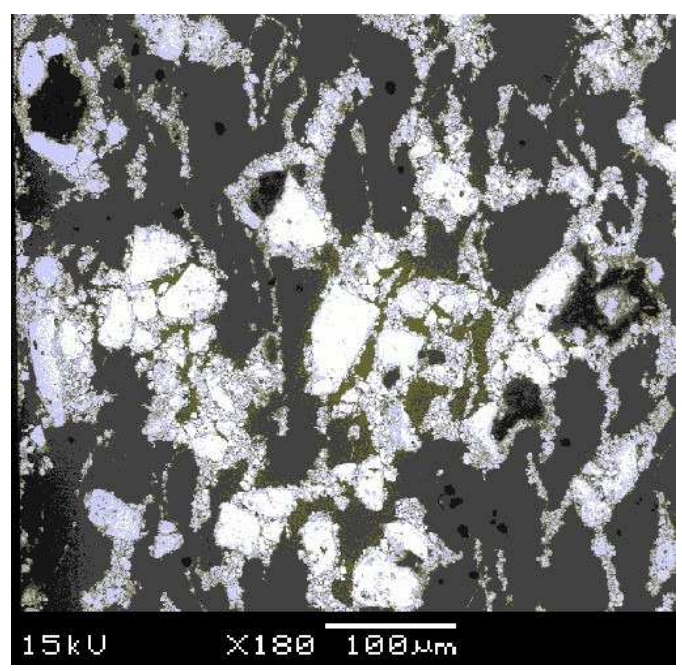

(a) value of $\epsilon$ for a pure PVC is equal to 3.7. When the volume fraction of the ceramics in PVC increases, the $\epsilon$ attains the magnitude of 29.5 and 36.2 for $\mathrm{PZT} / \mathrm{PVC}$ and $\mathrm{BaTiO}_{3} / \mathrm{PVC}$, respectively. The lower magnitude of the experimental values for a higher ceramics content, in comparison with the predicted results based on the Lichtenecker rule [1], may be due to the presence of isolated pores. The presence of the pores being visible in the SEM picture of composites (figure 2) in the shape of dark stains. The dimension particles of ceramics (bright objects having irregular shapes) is not higher than $75 \mu \mathrm{m}$.

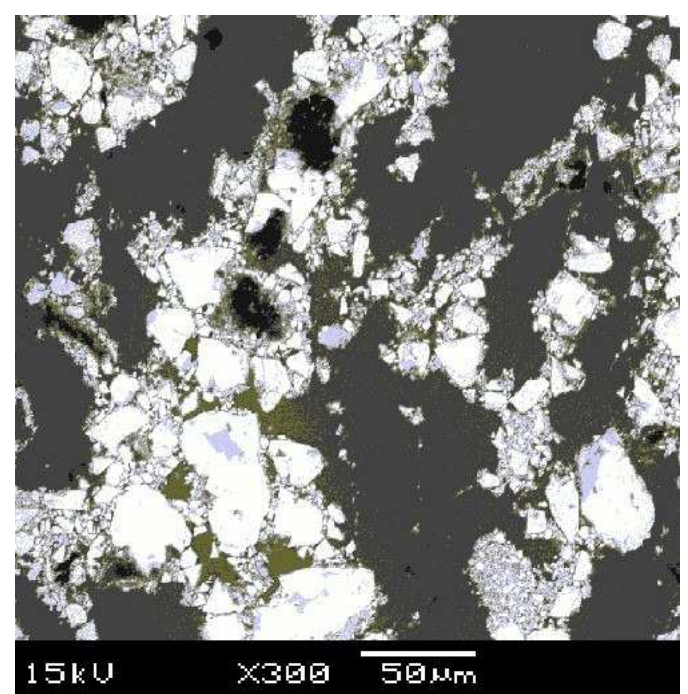

(b)

Figure 2. SEM picture of the microstructure of (a) PZT/PVC and (b) $\mathrm{BaTiO}_{3} / \mathrm{PVC}$ composites (with 30 vol\% filler) taken at magnifications of $\times 180$ and $\times 300$, respectively.

Figure 3 shows the dielectric constant $\epsilon^{\prime}$ behaviour for the PVC and the composites with temperature measured at $1 \mathrm{kHz}$. The values $\epsilon^{\prime}$ of the composites lay between the values for the polymer and the values for the ceramics as expected. The increment in dielectric constant for higher temperatures for $\mathrm{BaTiO}_{3} / \mathrm{PVC}$ is due to the approach of the Curie temperature $\left(T_{\mathrm{c}}\right)$ of $\mathrm{BaTiO}_{3}$ which occurs at $393 \mathrm{~K}$. Frequency variations in the dielectric constant and $\tan \delta$ of the investigated composites $\mathrm{PZT} / \mathrm{PVC}$ and $\mathrm{BaTiO}_{3} / \mathrm{PVC}$, measured at room temperature, are given in figure 4 . The dielectric losses for a higher frequency of the composites are lower than those of the polymer. The experiment revealed a relaxation process in the composites (both 
in $\mathrm{PZT} / \mathrm{PVC}$ and $\mathrm{BaTiO}_{3} / \mathrm{PVC}$ ) with a maximum at $\approx 150 \mathrm{kHz}$. The dielectric absorption is dominated by the polymer. The $\tan \delta$ curves show an increment near $1 \mathrm{MHz}$ which is probably due to the $\beta$ relaxation of polymer.
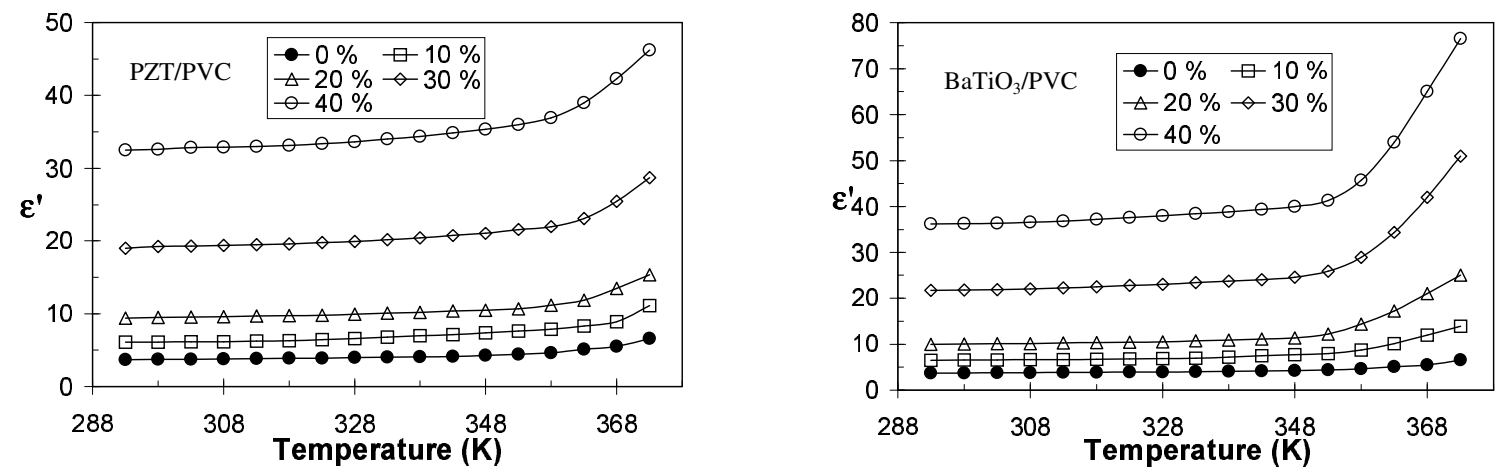

Figure 3. Temperature dependence of the dielectric constant $\epsilon^{\prime}$ for the composites with different ceramics contents.
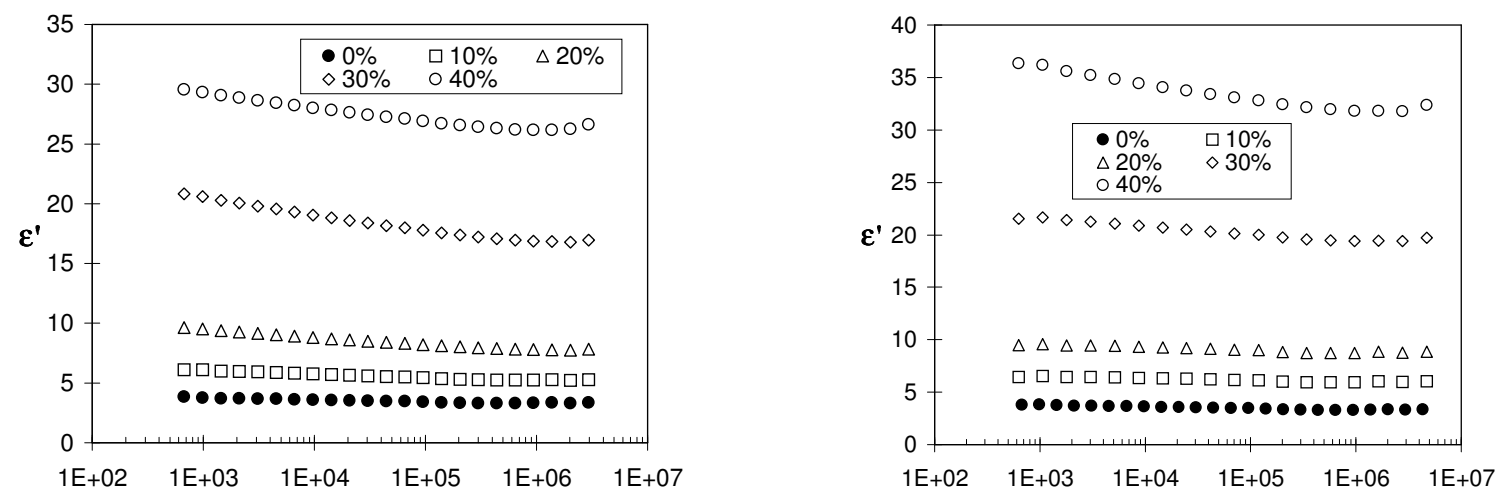

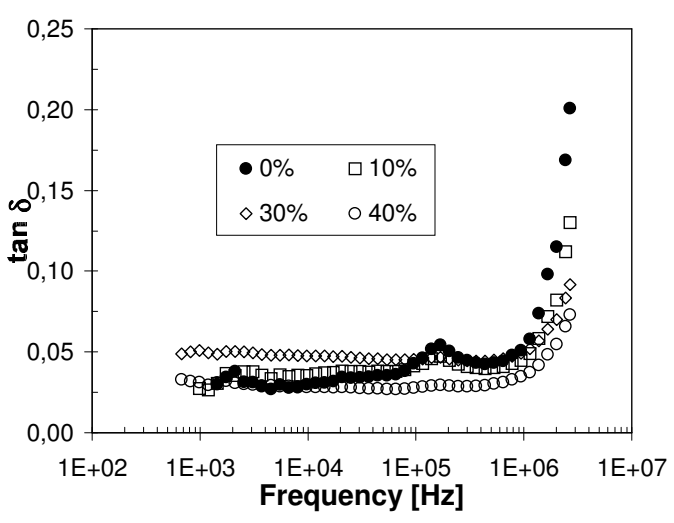

(a)

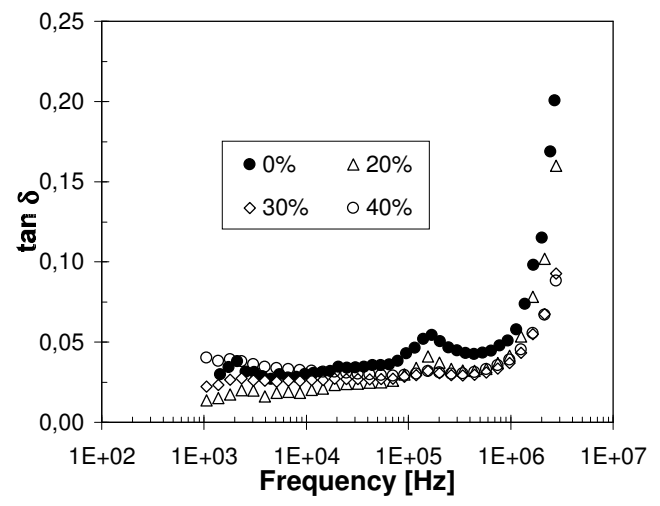

(b)

Figure 4. Frequency dependence of the dielectric constant $\epsilon^{\prime}$ and $\tan \delta$ for $\mathrm{PZT} / \mathrm{PVC}$ (a) and $\mathrm{BaTiO}_{3} / \mathrm{PVC}(\mathrm{b})$ composites.

The fragment of TSC thermograms of polarized films are characterized by the pure PVC and $\mathrm{BaTiO}_{3} / \mathrm{PVC}$ composites of different value current density peaks (figure 5 ). The thermogram of a PVC (curve $0 \%$ ) as $\alpha$ peak at $\approx 350 \mathrm{~K}$ is shown 


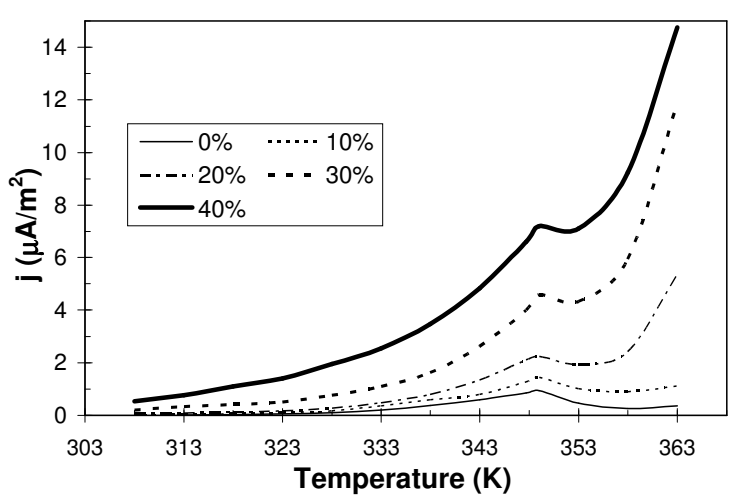

Figure 5. TSC thermograms for $\mathrm{BaTiO}_{3} / \mathrm{PVC}$ composites with different $\mathrm{BaTiO}_{3}$ contents. Conditions: $E_{\mathrm{p}}=4 \mathrm{MV} / \mathrm{m}, T_{\mathrm{p}}=373 \mathrm{~K}, t_{\mathrm{p}}=0.5 \mathrm{~h}$.

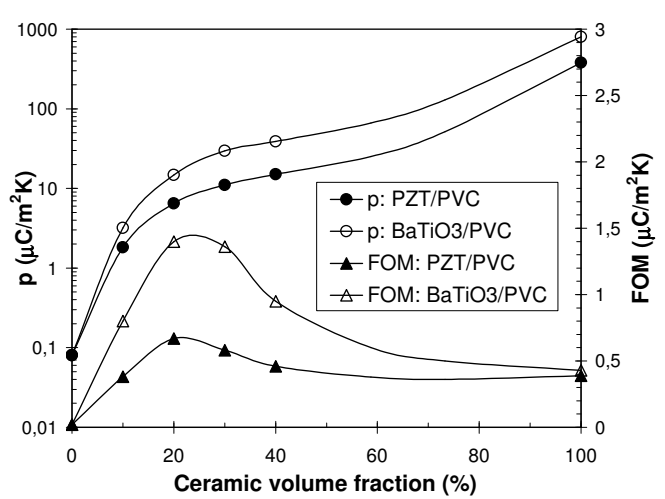

Figure 6. The depedence of the pyroelectric coefficients and pyroelectric Figure Of Merit (FOM) on the ceramics powder content.

as well. This indicates that the TSC $\alpha$ peak of polymer electrets is mainly due to the reorientation of dipolar main-chain segments [6]. Note that the location of the $\alpha$ peak corresponds to the glass-rubber transition of PVC-unplasticized. A high increase of current peaks of TSC of $\mathrm{BaTiO}_{3} / \mathrm{PVC}$ is observed when concentration of $\mathrm{BaTiO}_{3}$ rises in the composites. Temperature positions of those peaks are not changed. Moreover, the heights of these peaks depend on polarizing temperature and polarizing field. A similar effect is observed in PZT/PVC composites [7]. The increase of the electric charges, defined by TSC-peaks areas, as a result of admixing of a polymer by ferroelectric ceramics, profitably effects the electroactive properties of the composites. The increment in current density for higher temperatures for a composite is due to the approach of the $T_{\mathrm{c}}$ temperature.

Dependence of pyroelectric coefficient $p$ and pyroelectric Figure Of Merit (FOM) on the ceramics volume fraction at $343 \mathrm{~K}$ is shown in figure 6 .

For PVC, the measured value of $p$ is $0.08 \mu \mathrm{C} / \mathrm{m}^{2} \mathrm{~K}$. The dielectric constant was found to be equal to 3.7 and, thus, the pyroelectric $\mathrm{FOM}=p / \epsilon$ was $0.02 \mu \mathrm{C} / \mathrm{m}^{2} \mathrm{~K}$. With the growth of ceramics powder content value $p$ increases, too. For a ceramic volume fraction $40 \%$, the value $p$ for $\mathrm{PZT} / \mathrm{PVC}$ and $\mathrm{BaTiO}_{3} / \mathrm{PVC}$ reaches about $15 \mu \mathrm{C} / \mathrm{m}^{2} \mathrm{~K}$ and $35 \mu \mathrm{C} / \mathrm{m}^{2} \mathrm{~K}$, respectively. The measured pyroelectric coefficients of the composites are higher than the coefficient of $\beta$-PVDF $\left(10 \mu \mathrm{C} / \mathrm{m}^{2} \mathrm{~K}\right)$ [8]. The FOM achieves maximum value for concentrations of ceramics about $20 \%$ and it is higher than that of the pure ceramics. The measured $p$ and FOM of the composites are comparable with those parameters for other ferroelectric ceramic/polymer composites consisting of $\mathrm{PZT}$ or $\mathrm{BaTiO}_{3}$ ceramic $[1,2]$.

\section{Conclusions}

The dielectric and pyroelectric properties of $0-3 \mathrm{PZT} / \mathrm{PVC}$ and $\mathrm{BaTiO}_{3} / \mathrm{PVC}$ composites as a function of the volume fraction of the ceramic were investigated. PZT 
and $\mathrm{BaTiO}_{3}$ ceramics significantly modify their properties. Lower values of dielectric constant for higher ceramics volume fraction could be attributed to the presence of isolated pores. The pyroelectric activity increases with a growth of content of the ceramics in the composite. The pyroelectric coefficients of our samples are higher than the parameters for $\beta$-PVDF. The achieved pyroelectric FOM is higher than that of the pure ceramics. Furthermore, an increase of the FOM value in the obtained composites at higher temperatures, given by the ratio $p / \epsilon$, is conditioned by the value $\epsilon$ that is practically not changed within a temperature range $300-350 \mathrm{~K}$.

\section{References}

1. Nalwa H.S. Ferroelectric Polymers. New York, Basel, Hong Kong, Marcel Dekker Inc., 1995.

2. Dias C.J., Das-Gupta D.K. Ferroelectric Ceramic/Polymer Composite Electrets. - In: Electrets. (Ed. Gerhard-Multhaupt R.) Morgan Hill, CA, Laplacian Press, 1999, vol. 2, p. 193.

3. Dias C.J., Das-Gupta D.K. // IEEE Trans. Dielectric Electr. Insul., 1996, vol. 3, p. 706.

4. Lang S.B., Das-Gupta D.K. // Ferroelectrics Rev., 2000, vol. 2, p. 217.

5. Hilczer B., Kulek J., Markiewicz E., Kosec M. // Ferroelectrics, 2002, vol. 267, p. 277.

6. van Turnhout J. Thermally Stimulated Discharge of Polymer Electrets. Amsterdam, Elsevier Sci. Publ. Co., 1975.

7. Olszowy M. Piezoelectric and Pyroelectric Behaviour in PVC/PZT Composite Thin Films. - In: Proc. 6th Int. Conf. on Dielectric and Related Phenomena DRP 2000, Spala, 6-10 September 2000, p. 95.

8. Sakamoto, W.K., Kanada D.H.F., Das-Gupta D.K. // Math. Res. Innovat., 2002, vol. 5, p. 257. 


\section{Діелектричні і піроелектричні властивості композитів сегнетоелектричної кераміки і полі(вінил хлориду)}

\section{М.Ольшови}

Інститут фізики, Університет м. Зєльона Ґура

Польща, 65-516 Зєльона Ґура, вул. Шафрана, 4а

Отримано 24 жовтня 2002 р., в остаточному вигляді 14 квітня 2003 р.

Досліджено діелектричні і піроелектричні властивості композитів цирконату свинцю/полі(вінил хлориду) та титанату барію/полі(вінил хлориду). Еластичні композити виготовлено у вигляді тонких плівок (200-400 мкм) методом гарячого пресування. Порошки PZT та $\mathrm{BaTiO}_{3}$ у вигляді керамічних частинок з діаметром меншим за 0.75 мкм розпилено в матриці полівінилхлориду, при чому утворилися композити зі зв'язністю 0-3. Розподіл керамічних частинок у полімерній фазі досліджено за допомогою електронного скануючого мікроскопа. Також проведено аналіз термічно стимульованих струмів. Досліджено зміни діелектричних і піроелектричних характеристик композитів при зміні вмісту кераміки до 40\%. Діелектричні сталі виміряні у частотному діапазоні від 600 Гц до 6 МГц при кімнатній температурі. Піроелектричний коефіцієнт композиту $\mathrm{BaTiO}_{3} / \mathrm{PVC}$ при $343 \mathrm{~K}$ складає 35 мкКл/м² K, що вище, ніж у $\beta$-PVDF $\left(10 \mathrm{MKKл/ \textrm {M } ^ { 2 } \mathrm { K } )}\right.$

Ключові слова: піроелектричний композит, діелектричні властивості, піроелектричні властивості, PZT/PVC, BaTiO 3 /PVC

PACS: $77.84 . L, 77.70,77.84 . D$ 
